\title{
Induction of sublethal effects for the characterization of Olive groves under different pest management systems
}

\author{
José Alfonso Gómez-Guzmán", María Sainz-Pérez ${ }^{1}$, Ramón González-Ruiz²
}

\begin{abstract}
Currently, olive grove management in Spain responds to the three following clearly differentiated systems in order of decreasing area: Conventional Management (70\%), Integrated Pest Management (IPM) (26\%) and Ecological Management (4\%) systems. These are characterized by a decreasing dependence on synthetic insecticides and by different soil tillage intensities. They are also subject to different subside regulations and application regimen by the government, so their adequate characterization represents a factor of increasing importance, which is the object of this work.During the years 2017 and 2018, olive groves corresponding to the three types of management were selected, in which two series of plots were established. In one series, Dimethoate $40 \AA$ was applied, considering plots of the second series as control. After insecticide application, beneficial insects were monitored through the use of chromatic traps. The results allow elucidating two clearly different behavioral patterns in beneficial insects, depending on the use of insecticides: Conventional and IPM management, where repellency reaction is manifested, absent in the Ecological Management. Aspects about the induction of sublethal effects for the characterization of the different pest management systems are discussed. Indexing terms: Synthetic insecticides; natural enemies; Conventional management; Integrated Pest Control (IPM); Ecological Management.
\end{abstract}

\section{Indução de efeitos subletais para a caracterização de Olivais sob diferentes sistemas de manejo de pestes}

\section{Corresponding author: jagg0020@red.ujaen.es \\ Received: February 28, 2021 Accepted: May 17, 2021}

Copyright: All the contents of this journal, except where otherwise noted, is licensed under a Creative Commons Attribution License.

\section{(cc) $\mathbf{E Y}$}

Resumo- Atualmente, o manejo de olivais na Espanha responde a três modelos claramente diferenciados, por ordem decrescente de área: Manejo Convencional (70\%), Manejo Integrado de Pragas (MIP) (26\%) e Manejo Ecológico (4\%). Estes são caracterizados por uma dependência decrescente de inseticidas sintéticos e por diferentes intensidades de preparo do solo e estão também sujeitos a diferentes regulamentações e regimes de subsídios por parte do governo, visto que sua adequada caracterização representa um fator de crescente importância, sendo o objeto deste trabalho.Durante os anos de 2017 e 2018, foram selecionados olivais correspondentes aos três tipos de manejo, nos quais foram implantadas duas séries de parcelas. Em uma série, foi aplicado Dimetoato $40 \circledR$, considerando as parcelas da segunda série como controle. Após a aplicação do inseticida, insetos benéficos foram monitorados por meio da implantação de armadilhas cromotrópicas.Os resultados permitem elucidar dois padrões de comportamento claramente distintos em insetos benéficos, dependendo do uso de inseticidas: Manejo Convencional e MIP, onde se manifesta uma reação de repelência, ausente no manejo ecológico. Aspectos sobre a indução de efeitos subletais, na caracterização dos diferentes tipos de manejo, serão discutidos. Termos para indexação: Inseticidas sintéticos, inimigos naturais; Manejo Convencional; Manejo Integrado de Pragas (MIP); Manejo Ecológico.

\footnotetext{
${ }^{1} \mathrm{PhD}$ student at the Graduate Program in Molecular and Cellular Biology - University of Jaén. Campus Las Lagunillas, Jaén, Spain. E-mails: jagg0020@red.ujaen.es (ORCID 0000-0001-6921-2085),mariasainzperez@gmail.com ${ }^{\text {(ORCID 0000-0002-2109-0055) }}$

${ }^{2}$ Professor of the Department of Animal Biology, Plant Biology and Ecology - University of Jaén. Campus Las Lagunillas, Experimental and Health Sciences Building (B3) Jaén, Spain. E-mail: ramonglz@ujaen.es (ORCID 0000-0002-4946-3001)
} 


\section{Introduction}

Traditionally, pest control has been based on the systematic use of pesticides, which has led to an environmental crisis, with fatal consequences for ecosystems, negatively affecting biodiversity (VIVES DE QUADRAS, 1988), natural resources and the health of consumers (DEL PUERTO RODRÍGUEZ et al., 2014), also causing the appearance of emerging pests and the selection of insecticide-resistant lineages (CARRERO, 1996). At the same time, the suppression of plant communities in agricultural environments is the cause of strong reduction in the entomophagous activity of natural enemies of pests, which has led to a progressively greater dependence on synthetic insecticides.

In recent years, the policy of raising awareness about the risks of the indiscriminate use of pesticides has led to a change in the behavior of farmers, who are beginning to consider the importance of natural enemies in maintaining ecological balances (ARAMBOURG, 1986; LUCKMANN; METCALF, 1990), which reflected in a growing trend towards the adoption of environmentally friendly management practices. However, the Conventional Management system currently represents the highest proportion of Spanish crops (70\%) (BOLLERO et al., 2017). In these crops, herbaceous cover is excluded due to the regular application of herbicides and pests are managed through the application of synthetic insecticides.

Second, there is an area equivalent to $26 \%$ of olive groves under the Integrated Pest Management (IPM) system, (BOLLERO et al., 2017). The Conventional Management system represents a more environmentally friendly approach, including biorational criteria. In these crops, the application of synthetic insecticides is not ruled out, although it requires a more precise knowledge of the biology and ecology of pests and their natural enemies, as well as the introduction of population thresholds with the aim of suppressing unnecessary insecticide applications (EHI -EROMOSELE et al., 2013). IPM also contemplates the development of herbaceous covers, which are aimed at stimulating the proliferation of beneficial insects (CALABRESE et al., 2012; GÓMEZ et al., 2018).

In very smaller proportion, an area equivalent to $4 \%$ of olive groves present ecological certification (BOLLERO et al., 2017), which are characterized by the complete suppression of synthetic insecticides and the stimulation of populations of beneficial species, natural enemies of pests.

In the last twenty years, the granting of economic subsidies by the Ministry of Agriculture has been reflected in a notable increase in the area devoted to organic olive cultivation, in relation to the year 2001 (BOLLERO et al., 2017). Among requirements for obtaining organic certification, these crops must be open to periodic inspections, being also submitted to analysis of pesticide residues in fruits / oil. However, its reliability depends on various environmental factors, which highlights the need for applying alternative approaches. Among the different options, the diversity and relative abundance of populations of natural enemies should be revaluated by determining their adaptations to the different agroecosystem management systems, as well as by assessing and monitoring the effects that insecticide applications induce on their behavior.

Most studies on the effects of insecticides are focused on the lethality they produce in insects; however, due to their rapid degradation (light, heat, rain), large proportion of insects are affected only by sublethal doses (STARK et al., 1995), including beneficial entomofauna (LUND et al., 1979; HAYNES, 1988; DESNEUX et al., 2007), which has led to underestimating the real impact of insecticide applications (KEVAN, 1999; THOMPSON, 2003). Among the effects caused by sublethal doses, Haynes (1988), Lee (2000), Kongmee et al. (2004), Desneux et al. (2007), Correa et al. (2015), Haddi et al. (2015), França et al. (2017) indicate alterations of physiological, biological and behavioral processes in affected insects, such as hyperreflexia, irritability / repellency, and greater trend to start flight, avoiding contact with insecticide-impregnated surfaces. In these insects, adverse effects on their reproductive processes, in the search for a host, in feeding, in migration and dispersal have also been observed (LEE, 2000; SINGH; MARWAHA, 2000; MAZZI; DORN, 2012; FRANÇA et al., 2017; VÉLEZ et al., 2019). These alterations have been indicated for organochlorine compounds (KENNEDY, 1947; ROLFF; REYNOLDS, 2009), pyrethroids (VAN DAME et al., 1995; PIKE et al., 1982; QUISENBERRY et al., 1984; HAYNES et al., 1986; ROLFF; REYNOLDS, 2009), organophosphates (MOORE, 1980; ROLFF; REYNOLDS, 2009) and carbamates (ROLFF; REYNOLDS, 2009).

Among sublethal effects, behavioral alterations in insects exposed to sublethal doses provide the first barrier of the detoxification mechanism (VAN DAME et al., 1995; GEROLD; LAARMAN, 1967; GOULD, 1984; LOCKWOOD et al., 1984; PLUTHERO; SINGH, 1984; FRANÇA et al., 2017), which has contributed to a progressive reduction in their efficacy, and to the development of resistant lineages (LEE, 2000; SINGH; MARWAHA, 2000; FRANÇA et al., 2017). These alterations are therefore secondary effects that must be taken into account for a more precise assessment of the impact of insecticides (DESNEUX et al., 2007), and especially for the improvement of integrated pest control programs (GEORGHIOU, 1972; LOCKWOOD et al., 1984; PLUTHERO; SINGH, 1984; GUEDES et al., 2009).

The possibility of verifying the occurrence or absence of repellency phenomena to insecticides in populations of beneficial insects after their application, and in this case, verifying possible behavioral alterations among the different management systems, could provide 
information of interest for the characterization of crops. In parallel, the negative effect of insecticide applications on the entomophagous activity of insects suggests as complementary objective, the assessment of the predatory impact in the different management systems, which will allow a much more precise analysis of their advantages / disadvantages.

\section{Materials and methods}

The study was carried out in three olive groves in the municipality of Jaén (Andalusia, southern Spain) during the spring and summer of 2017 and 2018. The selected olive groves are representatives of the Conventional Management (CM), Integrated Pest Management (IPM) and Ecological Management (ECO) systems, respectively, which have been submitted to agricultural practices from the beginning of plantation. Table 1 shows the average volume of pesticide application for the control of some of the main phytoparasites of olive groves in crops submitted to these management systems. The distance between the Ecological system and the Conventional system is approximately $2.1 \mathrm{~km}$; while the distance between Ecological and IPM systems is about $4.6 \mathrm{~km}$. Likewise, the distance that separates Conventional and IPM systems is about $2.5 \mathrm{~km}$.

Conventional Management system (CM). Surface: 32 ha. Coordinates: $37^{\circ} 36^{\prime} 18.20^{\prime \prime} \mathrm{N} 3{ }^{\circ} 28^{\prime} 33.59^{\prime \prime} \mathrm{W}$. Olive groves are of the Picual variety, 20 to 30 years old, and are planted with density of 100 olive groves / hectare. Pre-emergence herbicides are regularly applied to keep olive groves free from spontaneous vegetation. Arthropod control is carried out using commercial organophosphate insecticides, regularly applied using Dimethoate ${ }^{\circledR} 40 \%$ (C) $(400 \mathrm{~g} / 1)(\mathrm{BASF})$ at concentration of $0.1 \%(100$ $\mathrm{cc} / \mathrm{hl}$ ), applied during spring (May-June) and autumn (September-October), with average annual frequency of three applications.

Integrated Pest Management system (IPM). Surface: 18 ha. Coordinates: $37^{\circ} 37^{\prime} 44.79$ " N 3 ' $26^{\prime} 32.75^{\prime}$ 'W. Olive groves are of the Picual variety, with planting age and density similar to those of the Conventional Management system. In this case, the growth of vegetation cover located in a band of approximately 2.5 $\mathrm{m}$, located in the central area between two contiguous rows of olive groves, is encouraged. In order to reduce water competition from the month of April, this cover is controlled by using brushcutter. Among species that compose this plant community associated with cultivation, the following stand out: Lolium rigidum Gaudin, Senecio vulgaris Linneo, Poa annua Linneo, Silene colorata Poiret, Diplotaxis virgata Candolle, Muscari neglectum Gussone, Sinapis alba Linneo, Equisetum arvense Linneo, Bromus madritensis Linneo, Convolvulus althaeoides Linneo, Phalaris minor Retzius, Daucus carota Linneo, Cirsium arvense Scopoli, and Anacyclus clavatus Persoon. Pest control is only carried out in compliance with the Integrated Production Regulation of the Protected Designation of Origin (PDO) Regulatory Council, and in cases in which pest population values exceed the established economic damage threshold. However, in any case, the insecticide commonly used is Dimethoate 40\% (C). The Conventional Management system allows less dependence on insecticides, making 1-2 applications per year.

Table 1. Characterization of the different olive grove management systems according to chemical treatments applied to different pests / pathogens. Period of 2007-2017; Ministry of Agriculture of Spain and Spanish Committee of Ecological Agriculture.

\begin{tabular}{|c|c|c|c|c|}
\hline & & Conventional & IPM & Ecological \\
\hline Pest/pathogen & $\begin{array}{c}\text { Pesticides } \\
\text { Active ingredients }\end{array}$ & $\begin{array}{l}\text { volume-weight } \\
\text { (avg/ Ha\&year) }\end{array}$ & $\begin{array}{l}\text { volume-weight } \\
\text { (avg/ Ha\&year) }\end{array}$ & $\begin{array}{l}\text { volume-weight } \\
\text { (avg/ Ha\&year) }\end{array}$ \\
\hline \multirow[t]{2}{*}{ Herb vegetation } & Glyphosate $(20 \%)$ & $0.3 \mathrm{~L} / \mathrm{Ha}$ & \multirow{2}{*}{--- } & \multirow{2}{*}{---} \\
\hline & + Oxifluorfen (3\%) & $4 \mathrm{~L} / \mathrm{Ha}$ & & \\
\hline Fusicladium oleagineum & Copper oxychloride (20\%) & $0.8 \mathrm{Kg} / \mathrm{Ha}$ & $0.8 \mathrm{Kg} / \mathrm{Ha}$ & --- \\
\hline Colletotrichum gloesporides & + Propineb $(15 \%)$ & & & \\
\hline \multicolumn{5}{|l|}{ Pseudomonas savastanoi } \\
\hline Aceria oleae & $\mathrm{S}(80 \%)$ & $1.4 \mathrm{Kg} / \mathrm{Ha}$ & $0.75 \mathrm{Kg} / \mathrm{Ha}$ & --- \\
\hline Prays oleae & Dimethoate $40 \%$ & $0.9 \mathrm{~L} / \mathrm{Ha}$ & $0.3 \mathrm{~L} / \mathrm{Ha}$ & --- \\
\hline Euzophera pinguis & Chlorpyrifos $48 \%$ & $1.5 \mathrm{~L} / \mathrm{Ha}$ & $0.75 \mathrm{~L} / \mathrm{Ha}$ & --- \\
\hline Phloeotribus scarabaeoides & Dimethoate $40 \%$ & $0.9 \mathrm{~L} / \mathrm{Ha}$ & $0.45 \mathrm{~L} / \mathrm{Ha}$ & --- \\
\hline Bactrocera oleae & Dimethoate $40 \%$ & $1.8 \mathrm{~L} / \mathrm{Ha}$ & $0.9 \mathrm{~L} / \mathrm{Ha}$ & --- \\
\hline
\end{tabular}


Ecological Management system (ECO). Surface: 30 ha. Coordinates: $37^{\circ} 37^{\prime} 24.38^{\prime} \mathrm{N} 3^{\circ} 29^{\prime} 51.22^{\prime \prime} \mathrm{W}$. Olive groves are of the picual variety, 20 to 25 years old, with no application of synthetic chemicals, including pesticides and fertilizers. The IPM system allows the proliferation of natural vegetation cover during the autumn, winter and spring. In this system, pest control depends almost exclusively on the entomophagous activity of natural enemies. The species that compose most part of this cover are the same as in the case of the IPM system, although, in this case, vegetation characteristic of the Mediterranean forest is also included (especially in adjacent areas), among which Quercus ilex Linneo, Rosmarinus officinalis Schleid and Stipa tenacissima Kunth stand out.

\section{Experimental design}

The study was carried out during the anthophagous and carpophagous generations of the olive moth, Prays oleae (Bernard, 1788) (Lepidoptera: Praydidae), which occurs between mid-spring and mid-summer, a period in which beneficial insects, like phytophages, have intense activity (RAMOS and RAMOS, 1990). During this interval, insecticidal applications are frequent (Conventional Management and IPM systems) (Table 1 ), commonly based on $40 \%$ Dimethoate ${ }^{\circledR}$ for the control of pests such as olive moth, $P$. oleae, olive beetle Phloeotribus scarabaeoides (Bernard, 1788) (Coleoptera: Curculionidae: Scolytinae), or olive scale Saissetia oleae (Olivier, 1791) (Hemiptera: Coccidae), among others.

In each of the three selected olive groves, 6 plots of $30 \times 30 \mathrm{~m}$ (16 olive groves) were established (Figure 1) with minimum distance between them of $150 \mathrm{~m}$. In 3 of the 6 plots of each randomly selected olive grove, experimental application based on organophosphate Dimethoate $40 \%$ (C) was performed (400 g / 1) (BASF). This commercial insecticide was used because it is the most commonly used product, which was applied at concentration of $0.1 \%(\mathrm{v} / \mathrm{v})$ by means of hydraulic knapsack sprayer (MATABI Evolution 16 (C) with 161 capacity. The proportions of olive groves experimentally treated (16 33 olive groves) represent $0.8 \%, 1.5 \%$ and $0.9 \%$ for Conventional Management, IPM and Ecological Management systems, respectively, which in the latter case does not represent an inconvenient to maintaining organic certification. On the other hand, in the remaining 3 plots considered as control, distilled water was applied on olive groves. Both in insecticide-treated plots and in control plots, it was ensured that the volume applied per grove was homogeneous, of about 2.51 , and that during application, environmental conditions were atmospheric calm, with wind speed of about 4 or $5 \mathrm{~km} / \mathrm{h}$. Treatments were carried out on May 10 (2017) and June 2 (2018), both dates coinciding with the flowering phenological stage of olive groves (stages FI-F2).
In the 6 plots of each olive grove, the community of natural enemies was monitored through the passive sampling method based on the use of yellow chromatic traps. This type of sampling based on the movement of arthropods towards the traps (PASCUAL et al., 2014) has provided excellent results in previous studies, and has proved to be an easily replicable method (TRDAN et al., 2005; GONZÁLEZ-RUIZ; GÓMEZ-GUZMÁN, 2019).

Immediately after insecticide application, chromatic traps were placed at a rate of 1 per grove, in all olive groves of the 6 plots. Traps, measuring $20 \mathrm{~cm} \mathrm{x} 40 \mathrm{~cm}$, were placed approximately $1.5 \mathrm{~m}$ from the ground and in the southern sector of olive groves in order to optimize the sampling to the microclimatic preferences of natural enemies during the spring and summer months. Traps were removed and renewed every 5 days, establishing two sampling intervals in each year of study: May 10-15 and May 15-20 in 2017 and June 2-7 and June 7-12 in 2018.

To minimize the effect of pseudo-replication (HURLBERT, 1984), two plots were randomly selected in each sampling interval in each olive grove, one treated and one control. This design implies, for each olive grove and in each sampling interval, a total of 32 replicates: 16 of them corresponding to a control plot and 16 corresponding to a treated plot.

At the laboratory, traps were temporarily stored in cold chamber $\left(4^{\circ} \mathrm{C}\right)$ and later examined by means of magnifying glass binoculars for the taxonomic determination and quantification of species of captured natural enemies. For the determination and taxonomic quantification, the following criteria were applied:

a. Entomophagous importance. Species associated with at least one olive pest species (ARAMBOURG, 1986; HODKINSON; HUGHES, 1993; ANDRÉS-CANTERO, 1997; GUERRERO GARCÍA, 2003; BURRACK et al., 2009).

b. Ecological adaptability. Species present in a wide range of agricultural and / or forest ecosystems.

c. Insects whose larval development period is exceptionally long, and therefore more likely of being affected by insecticide applications. 


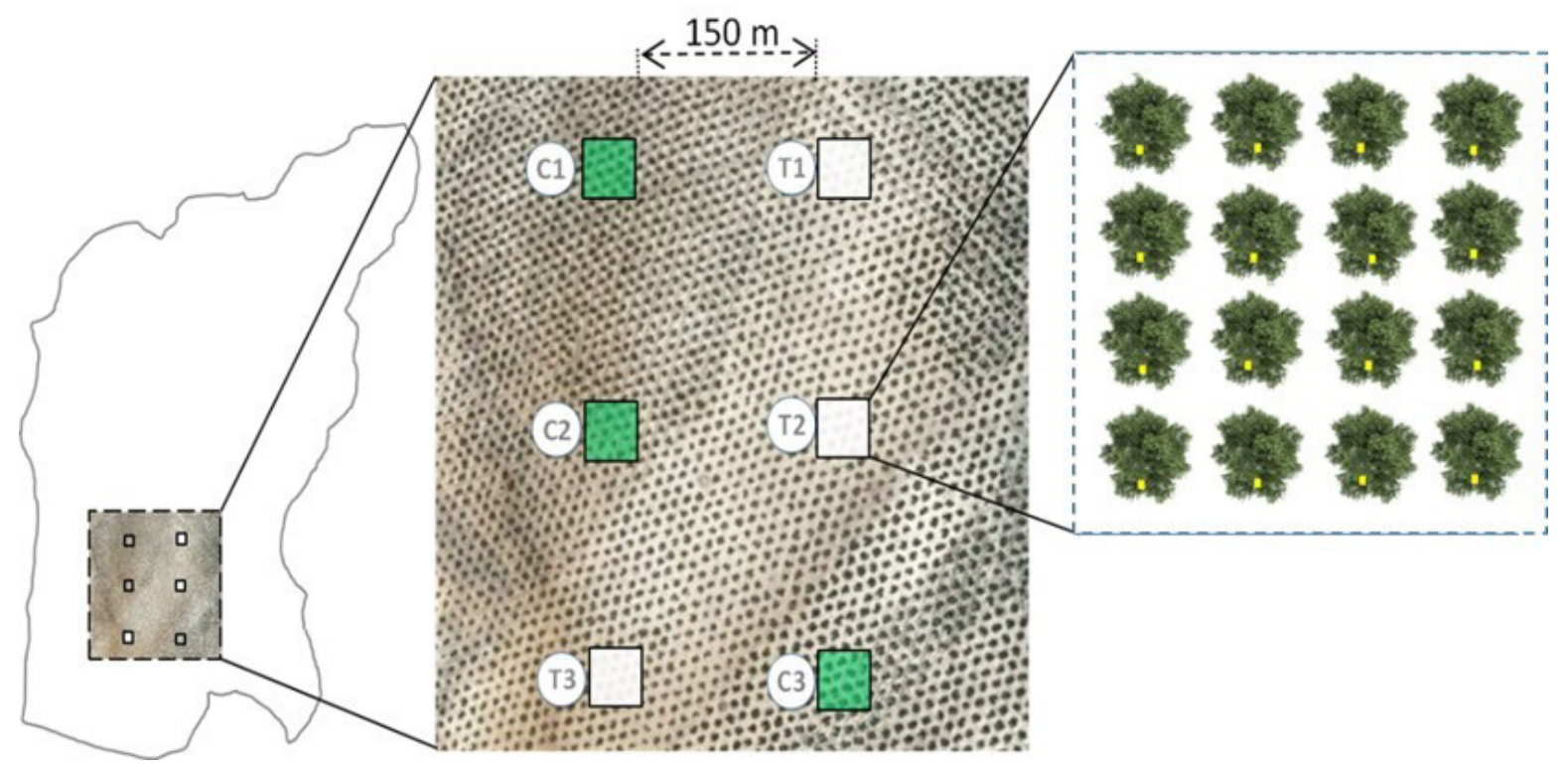

Figure 1. Distribution scheme of treated (T) and control (C) plots within the Ecological management system.

\section{Evaluation of the entomophagous activity}

The evaluation of the entomophagous activity selected the main pest species in olive groves of this study, olive moth, $P$. oleae, and its main predators, species of the Chrysoperla carnea s.l. complex (STEPHENS, 1836) (Neuroptera: Chrysopidae), in which species Chrysoperla agilis (HENRY, 2003) (Neuroptera: Chrysopidae) stands out due to its greater abundance (BOZSIK et al., 2009). During the summer of 2017, between mid-July and midAugust, and coinciding with the oviposition period of $P$. oleae, olive grove samples were taken at 10-day intervals. On each sampling date, 4 olive groves were randomly selected from each of olive groves, collecting 100 fruits from each of the four cardinal directions. Harvested olives were examined in the laboratory, where the number of $P$. oleae eggs in each olive was counted. According to methodology described by Ramos and Ramos (1990), differentiation between live eggs, those that had already hatched and those that had been predated by lacewings was performed (Neuroptera: Chrysopidae), as these are those that mostly exert oophagous predation in the anthophagous generation of $P$. oleae (RAMOS; RAMOS, 1990). The following parameters were recorded:

Hatching rate: \% of eggs hatched in relation to the sum of live and hatched eggs.

Predation rate: \% of predated eggs in relation to the sum of live, predated and hatched eggs.

\section{Statistical analysis}

For the statistical analysis of data, the Statgraphics Centurion XVII statistical package (2016) was used. Normality of distributions has been verified using the Shapiro-Wilk normality test. If data do not have normal distribution, the Kruskal-Wallis test is applied to determine possible significant differences among the different management systems. To compare the capture values of natural enemy species between two different management systems, the Mann-Whitney U test was used. To compare the capture values of each beneficial insect in treated and control plots within the same management system, the Mann-Whitney U test was used. To determine significant differences between predation rates of lacewings in the different management systems, analysis of variance (ANOVA) was performed. Finally, to compare the predation values among the different management systems, the Tukey's HSD (honestly significant difference) test was applied.

\section{Results and discussion}

\section{Ecology of captured beneficial insects}

Among captured insects, 10 species that met the specified criteria were selected ( 6 predators and 4 parasitoids) for being common in olive groves of southern Spain (ARAMBOURG, 1986; VARELA-MARTÍNEZ; GONZÁLEZ-RUIZ, 1999). Among entomophagous predators, the highest capture rate corresponds to Aeolothrips intermedius (Bagnall, 1934) (Thysanoptera: Aeolothripidae), which is a cosmopolitan species present in a wide range of crops (DE LIÑÁN, 1998; NIKOLOVA et al., 2015). In olive groves, they feed on Liothrips oleae (Costa, 1857) (Thysanoptera: Phlaeotripidae), as well as on various phytophagous mites such as Aceria oleae (Nalepa, 1900) (Trombidiformes: Eriophyidae) and Oxycenus maxwelli (Keifer, 1939) (Trombidiformes: Eriophyidae). 
Species of the $C h$. carnea complex, especially $C h$. agilis, have been frequently found. In studies carried out in southern Spain on the carnea complex (BOZSIK et al., 2009), four cryptic species that inhabit olive groves of southern Spain have been reported: Chrysoperla affinis (STEPHENS, 1836) ex Chrysoperla kolthoffi (Navas, 1927) (THIERRY et al., 1998); Chrysoperla lucasina (Lacroix, 1912) (HENRY et al., 2001); Ch. carnea sensu stricto (THIERRY et al., 1998) or Chrysoperla pallida (Henry, 2002); and Ch. agilis (HENRY et al., 2003). These studies revealed the presence of these cryptic species in Andalusian olive groves, with $C h$. agilis being the dominant species (> 90\%) (BOZSIK et al., 2009), which is consistent with this study. In olive groves, species of the carnea complex are very effective predators in the natural control of olive moth P. oleae (BERNARD, 1788) (BOZSIK et al., 2009), of hemipterans psyllids such as Euphyllura olivina (Costa, 1839) (Hemiptera: Psyllidae) and species of Coccidae and Diaspididae families.

Among predators, Anthocoris nemoralis (FABRICIUS, 1794) (Hemiptera: Anthocoridae) and Orius laevigatus (FIEBER, 1860) (Hemiptera: Anthocoridae) also stand out. These species are frequently present in a wide range of agricultural crops, where nymphs and adults feed on numerous phytophagous species. In olive groves, they feed on olive psylla E. olivina (ANDRÉS-CANTERO, 1997), olive thrips, L. oleae (ARAMBOURG, 1986; BEJARANO-ALCÁZAR et al., 2011) and olive moth, P. oleae (ARAMBOURG, 1986).

Ladybugs (Coleoptera: Coccinellidae), especially Coccinella septempunctata (Linnaeus, 1758), play an important role in the control of several olive grove pests such as $S$. oleae, Parlatoria oleae (Colvée, 1880) (Hemiptera: Diaspididae), Lepidosaphes ulmi (LINNAEUS, 1758), (Hemiptera: Diaspididae) (ARAMBOURG, 1986), and Aspidiotus nerii (BOUCHE, 1833) (Hemiptera: Diaspididae) (ANDRÉS-CANTERO, 1997).

Among the less abundant predators, snakefly, Harraphidia laufferi (NAVÁS, 1915) (Raphidioptera: Raphidiidae) stands out. Its larval development takes place in the olive grove bark, feeding on P. scarabaeoides larvae (GONZÁLEZ-RUIZ, 1989), as well as on Euzophera pinguis eggs and larvae (Haworth, 1811) (Lepidoptera: Pyralidae) (ROZAS; GONZÁLEZ-RUIZ, 2017). During its adult stage, it feeds on the nymphs of olive psylla, $E$. olivina.

Among parasitoids, the most frequent species is Pnigalio mediterraneus (FERRIÈRRE; DELUCCHI, 1957) (Hymenoptera: Eulophidae), an ectoparasitoid of second- and third-instar larvae of the olive fly Bactrocera oleae (ROSSI, 1790) (Diptera: Tephritidae), as well as larvae of several miner microlepidopterans, including $P$. oleae. Pnigalio mediterraneus does not present diapause, and remains active throughout the winter, causing high parasitism rates, which makes it a very relevant species within the complex associated with olive fly (ARAMBOURG, 1986).
Chelonus elaeaphilus (Silvestri, 1908) (Hymenoptera: Braconidae) and Ageniaspis fuscicollis (Dalman, 1820) (Hymenoptera: Encyrtidae) are parasitoids specifically associated with olive moth $P$. oleae in the Mediterranean area (CAMPOS, 1981; ARAMBOURG, 1986; CARRERO, 1996; SÁNCHEZ; LÓPEZ-VILLALTA, 1993; KATSOYANNOS, 1992) and in Portugal, reaching high parasitism rates (NAVE et al., 2017). Chelonus elaeaphilus attacks larvae and during its development, it has two endophageal stages and a third ectophagous stage, while A. fuscicollis attacks eggs, and adults emerge a few days later than P. oleae (ARAMBOURG, 1986). Tetrastichus cesirae (Russo, 1938) (Hymenoptera: Eulophidae) is a relatively polyphagous species associated to olive beetle $P$. scarabaeoides, olive scale $S$. oleae, olive leaf gall midge Dasineura oleae (LOW, 1885) (Diptera: Cecidomyiidae), olive gall midge, Lasioptera berlesiana (PAOLI, 1907) (Diptera: Cecidomyiidae), red olive scale Chrysomphalus dictyospermi (MORGAN, 1889) (Hemiptera: Diaspididae) (ANDRÉS-CANTERO, 1997), and olive thrips L. oleae (ARAMBOURG, 1986).

\subsection{Abundance of beneficial insects according to the different agricultural management system (control plots)}

The normality test indicates that the capture distributions of selected species do not follow a parametric distribution (Shapiro-Wilk: $\mathrm{p}<0.001$ ), which is frequent in this type of sampling (GONZÁLEZ-RUIZ; GÓMEZGUZMÁN, 2019; GÓMEZ-GUZMÁN et al., 2017). Data from control plots during the years 2017 and 2018 indicate the existence of statistically significant differences between capture values in the different pest management systems (Figure 2). The maximum capture values correspond to the Ecological Management system, minimum values to the Conventional Management system, and intermediate values to the IPM system, although in this case, values are more similar to the Conventional system. The absence of synthetic insecticides in the Ecological Management system would explain the higher capture frequency, with values up to 10 times higher in most species in relation to Conventional and IPM management systems. Likewise, the distinctive presence of species such as $H$. laufferi, absent in the Conventional system and practically absent in the IPM system, stands out in the Ecological system. Unlike the other species, this one has an exceptionally long life cycle, requiring larvae a period even longer than two years for their full development (ASPÖCK, 2002; PANTALEONI, 2007), which represents a more than remarkable increase in the frequency of exposure to the toxin, and the risk of suffering the lethal effects of insecticide applications, which explains its practical absence in Conventional and IPM systems. 


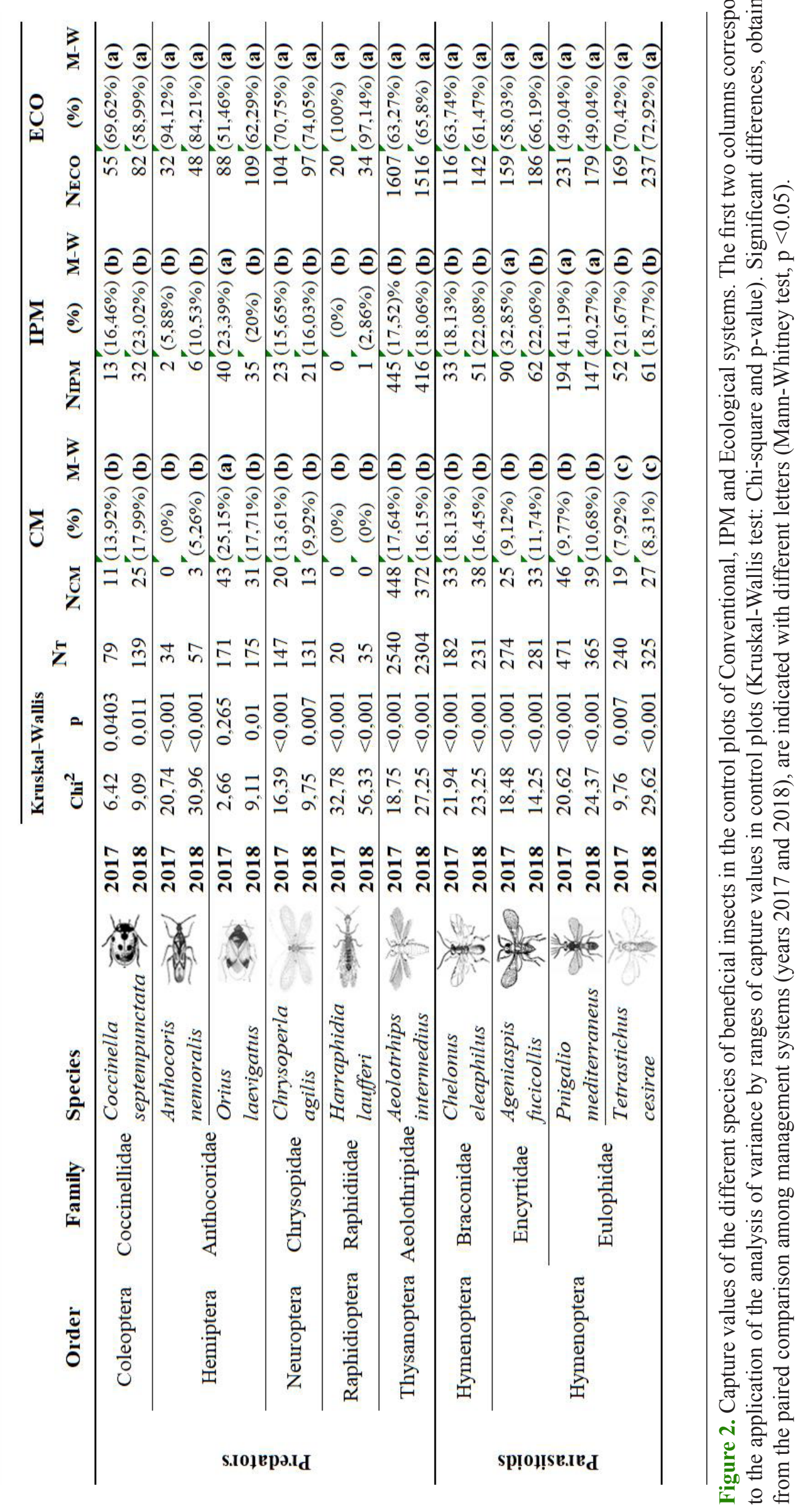


The similarity between Conventional and IPM systems (Figure 2, Mann-Whitney) is evident when considering the abundance of most beneficial insects, with few exceptions, such as $P$. mediterraneus, A. fuscicollis and T. cesirae, whose presence is superior in the IPM system. In these crops, insecticide Dimethoate $40 \%$ is frequently (IPM) or constantly used (Conventional) (MORENO; SORIANO, 2010), which could explain the similarities found between them. This fact is very striking, given that IPM incorporates differential elements compared to the Conventional system, such as the presence in the cultivation of herbaceous cover (CALABRESE et al., 2012) and the establishment of decision thresholds whose purpose is to limit the frequency of insecticide application. Therefore, data suggest the need to readjust IPM crop management protocols, most likely giving priority to insecticides such as those of natural origin, or those of biological origin, as they are less aggressive and more favorable alternatives for beneficial insects (NIKOLOVA et al., 2015).

\subsection{Evaluation of the experimental insecticide application (treated plots)}

Data obtained from treated plots show a very similar pattern in Conventional and IPM systems for most of the beneficial species (Figures 3 and 4), with significantly higher capture values in treated plots compared to control ones. Unlike previous ones, in the Ecological management system, captures of most cases are significantly higher in control plots compared to treated plots, which reveals two clearly different behavioral patterns in the populations of beneficial insects, according to the presence or absence of insecticides in the crop management:

In Conventional and IPM systems, the increase of captures in treated plots could be explained by the fact that the beneficial insects in these systems would very probably have developed resistance mechanisms, since the application of experimental insecticide induces a repellency reaction, which may explain the greater trend of insects to land on insecticide-free surfaces, such as chromatic traps. Regarding this phenomenon, Lee (2000), Singh and Marwaha (2000) indicate that the regular use of insecticides in agroecosystems triggers the selection of lineages that are progressively better adapted to elude the action of the insecticide, unlike wild lineages, typical of agroecosystems in which synthetic insecticides are not applied. The stimulation of the locomotor behavior in insecticide-affected individuals has also been reported by Haynes (1988) and França et al. (2017), who point out that the regular application of insecticides causes uncoordinated and convulsive reactions in insects, which allow them to increase their chances of survival (LEVINSON, 1975). Among anomalies induced in insecticide-affected insects, alterations in the search for the host, dispersal flight, feeding, reduction in longevity, in development rate, in fertility, and changes in the sexual ratio have been reported (BEEMAN; MATSUMURA,
1978; HAYNES, 1988; LEE, 2000; SINGH; MARWAHA, 2000; FRANÇA et al., 2017). Although these effects do not cause short-term mortality, they are very negative for the protection of the community from natural enemies, which requires improving the compatibility between chemical control and biological control (AIL-CATZIM et al., 2015; FRANÇA et al., 2017).

The repellency reaction in treated plots (IPM, Conventional) may explain that species whose presence goes almost unnoticed in control plots, such as $A$. nemoralis, present relatively high capture values in areas where the insecticide has been applied.

Unlike Conventional and IPM systems, in the Ecological system, the wild populations of beneficial insects have not developed resistant lineages, since their greater susceptibility to the insecticide would explain higher capture values in control plots, as observed (Figures 3 and 4).

The regular use of synthetic insecticides, or their suppression, allows establishing a clear correspondence with the two behavioral patterns described in entomophagous species. Consequently, the possibility of using the technique based on the experimental application of insecticides on a small scale, and the subsequent monitoring of the populations of beneficial insects, can represent a complementary tool of great interest for the determination of Ecological crops, allowing their identification with respect to management based on the use of synthetic insecticides.

\subsection{Influence of the management system on the predatory activity}

Data about the impact of predation on the carpophagous generation of the olive moth coincide in pointing almost exclusively to Ch. carnea s. lato as the main group of associated species, based on their prevalence (CANARD, 1979; ALROUECHDI, 1980; CAMPOS; RAMOS, 1985). In southern Spain, the predatory activity of larvae controls large part of the egg population of the carpophagous generation of $P$. oleae, having indicated $C h$. agilis as the most abundant within the Ch. carnea complex, reaching predation rates greater than 90\% - 95\% (GONZÁLEZ-RUIZ et al., 2008).

In biotopes studied here, oviposition corresponding to the carpophagous generation of $P$. oleae, and the hatching of eggs took place in the months of July and August (2017), observing that predation data adequately fit to a parametric distribution (Shapiro-Wilk: $\mathrm{W}=0.873$; $p>0.05$ ). The hatching rates of olive moth eggs during this period, and predation rates are shown in Table 2 . 


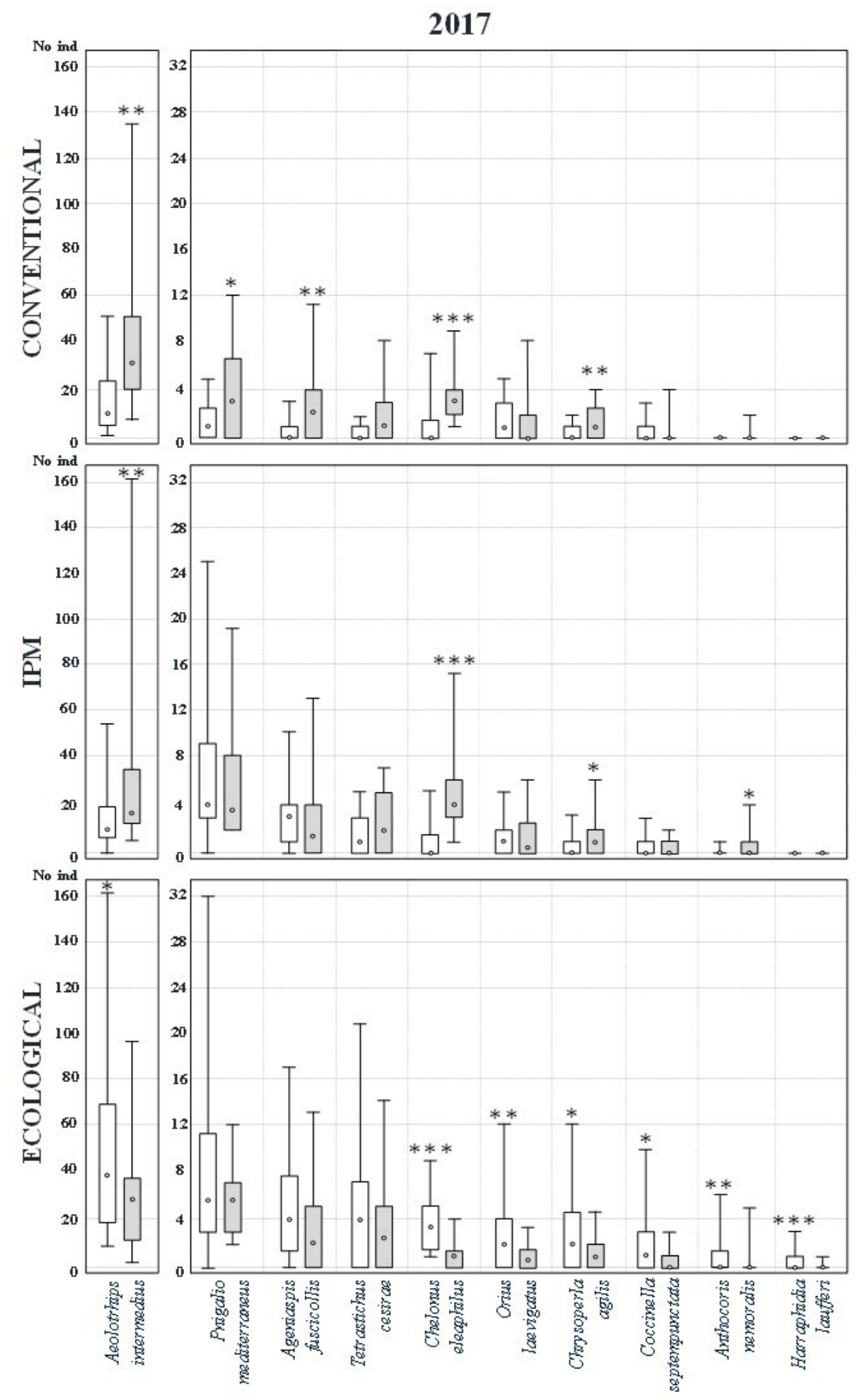

Figure 3. Statistical parameters (median, minimum, maximum and Q25-Q75 interval) corresponding to the year 2017 of beneficial insects captured in control (white) and treated (gray) plots in Conventional, IPM and Ecological management systems. Asterisks indicate significant differences [Mann-Whitney test; $\mathrm{p}<0.05(*) ; \mathrm{P}<0.01(* *), \mathrm{p}<0.001(* * *)$ ]. 


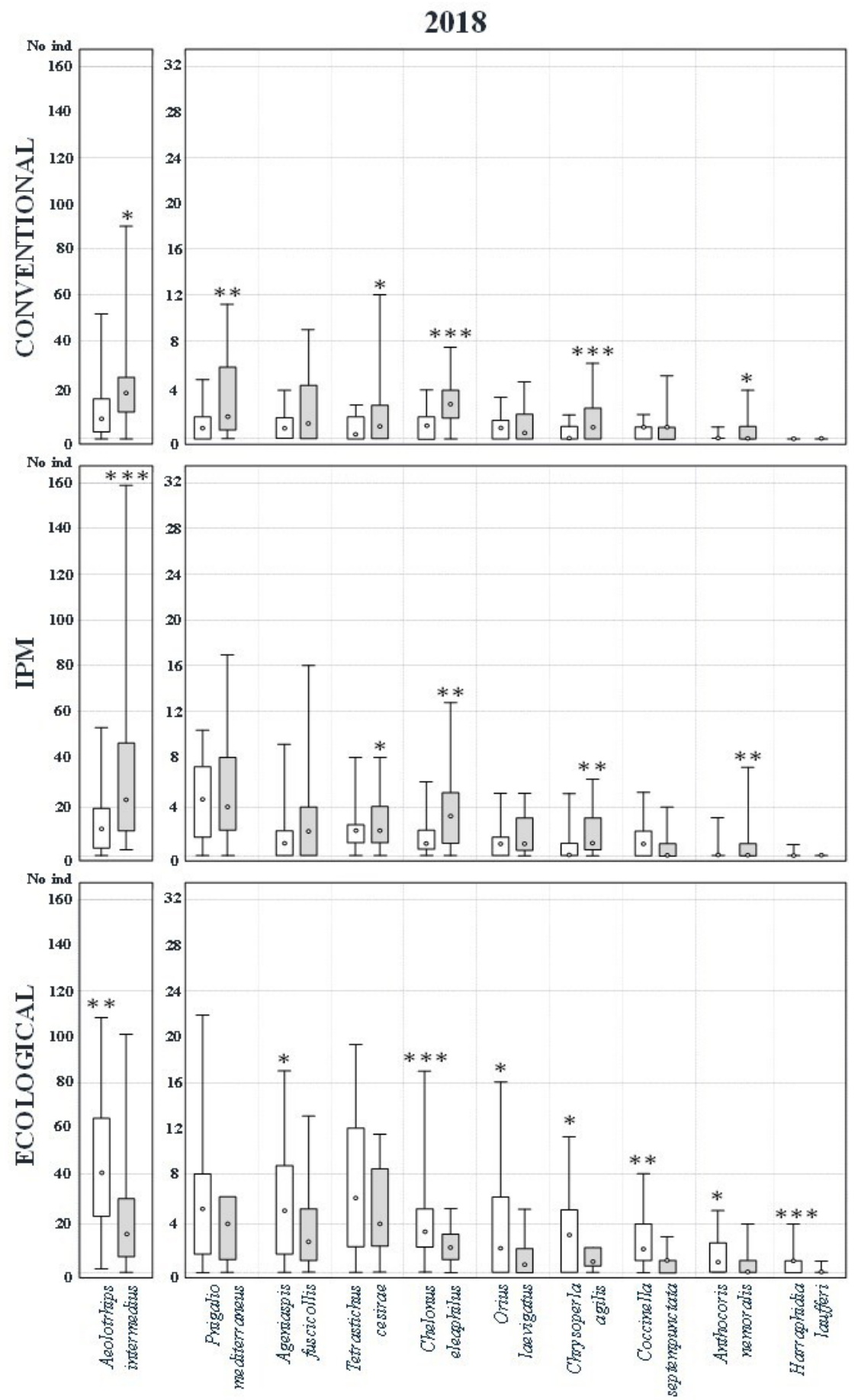

Figure 4. Statistical parameters (median, minimum, maximum and Q25-Q75 interval) corresponding to the year 2018 of beneficial insects captured in control (white) and treated (gray) plots in Conventional, IPM and Ecological management systems. Asterisks indicate significant differences [Mann-Whitney test; $\mathrm{p}<0.05\left(^{*}\right) ; \mathrm{P}<0.01(* *), \mathrm{p}<0.001(* * *)$ ]. 
Table 2. Predation rates (X: average, SE: standard error) on the $P$. oleae egg population by lacewings in the control plots of Conventional (CM), IPM and Ecological (ECO) management systems during the oviposition period (early July to mid-August). The average percentages of olive moth hatched eggs during the sampling period are indicated. Significant differences are indicated with different letters (Tukey's HSD test, $\mathrm{p}<0.05$ ).

\begin{tabular}{|c|c|c|c|c|c|c|}
\hline \multirow{3}{*}{ sampling date } & \multicolumn{6}{|c|}{ egg predation $(\%)$} \\
\hline & \multirow{2}{*}{$\begin{array}{c}\text { egg hatching } \\
(\%)\end{array}$} & \multirow{2}{*}{$\begin{array}{c}\mathbf{C M} \\
\mathbf{X} \pm \mathbf{S E}\end{array}$} & \multirow{2}{*}{$\begin{array}{c}\text { IPM } \\
X \pm S E\end{array}$} & \multirow{2}{*}{$\begin{array}{c}\text { ECO } \\
\mathbf{X} \pm \mathrm{SE}\end{array}$} & \multicolumn{2}{|c|}{ ANOVA } \\
\hline & & & & & $\mathbf{F}$ & $p$ \\
\hline July 17th & 12,8 & $85,8 \pm 1,99$ (b) & $82,54 \pm 0,27$ (b) & $92,23 \pm 0,37$ (a) & 17,36 & 0,003 \\
\hline July 27th & 25 & $65,86 \pm 0,74(\mathbf{c})$ & $78,80 \pm 2,11$ (b) & $91,37 \pm 0,59$ (a) & 91,55 & $<0,001$ \\
\hline 6th August & 74,1 & $76,11 \pm 3,05$ (b) & $85,64 \pm 7,23$ (ab) & $96,00 \pm 0,63$ (a) & 4,78 & 0,047 \\
\hline August 16th & 96,1 & $57,95 \pm 4,68$ (c) & $77,04 \pm 2,33$ (b) & $90,49 \pm 0,18$ (a) & 29,3 & $<0,001$ \\
\hline General Average & -- & $71,43 \pm 3,41(\mathbf{c})$ & $81,01 \pm 1,96(\mathbf{b})$ & $92,52 \pm 0,66$ (a) & 20,99 & $<0,001$ \\
\hline
\end{tabular}

Predation values were relatively high comparing the three management systems, ranging from $58 \%$ to $96 \%$. Throughout this period, the number of eggs laid on fruits increases gradually, which explains the reductions in predation rates, especially between the third and fourth samplings. Percentages corresponding to August $16^{\text {th }}$ are those that most accurately report the final predation values, as they correspond to the completion of the oviposition curve.

The maximum values corresponded to the Ecological management system (general average of $92.52 \%$ ); in the IPM system, values were significantly lower in three of the four samplings, with general average of $81.00 \%$. The lowest predation rates corresponded to the Conventional management system, where the general average was $71.43 \%$. A very similar value $(74.7 \%)$ has been reported by Ramos and Ramos (1990) who, in their 20 -year study of conventional management system in southern Spain, indicate average values of $71 \%$ in most $(60 \%)$ of the years.

The results of this study show an inverse relationship between frequency of pesticide application and the predatory efficacy of lacewings, which is most likely due to the higher mortality of chrysopid adults and larvae in Conventional and IPM systems. From these data, it is clear that insecticidal applications for the control of $P$. oleae during the carpophagous generation would not only be unnecessary, but even more counterproductive, in view of the high predation rates in the Ecological management system. However, it is a striking fact to find surprisingly high predation rates in Conventional and IPM systems, which is undoubtedly related to the relatively high capacity of lacewings to develop tolerance to insecticides (BOZSIK, 2008; KHAN-PATHAN et al., 2008). This fact, together with their relative easy breeding under controlled conditions, and their relatively short development cycle, has made these natural enemies excellent agents for use in IPM programs (BOZSIK et al., 2009).

\section{Conclusions}

The relative abundance values of the different beneficial species were much higher in the Ecological management system compared to Conventional and IPM systems.

The results allow differentiating two behavioral patterns in the populations of most natural enemies, clearly different from each other, depending on the application or not of synthetic insecticides in the usual crop management:

On the one hand, in olive groves where synthetic insecticides (Conventional, IPM) are applied, results are consistent with the existence of resistant lineages.

On the other hand, in the Ecological management system, results are consistent with the absence of resistant lineages.

The possibility of discriminating Ecological crops by means of small-scale insecticide applications in the pilot areas of crops can be a tool of great interest, allowing them to be identified with respect to any other type of management that includes the use of synthetic insecticides.

The greater dependence on insecticidal applications for pest control in Conventional and IPM systems negatively affects the predatory efficacy of lacewing larvae. The maximum predation values correspond to the Ecological system, which justifies the highest capture rate of Ch. agilis in this management system.

Finally, as a complementary conclusion, agricultural technicians should be warned about the very probable possibility of not considering the repellency factor of insects in areas submitted to insecticide applications, which could suggest erroneous interpretations of capture values in chromatic traps (commonly used in olive growing). This error consists in considering exclusively the chromatic attraction and extrapolating the number of captured individuals as a representative or proportional index of their population size in the crop. 


\section{References}

AIL-CATZIM, C.E.; CERNA-CHÁVEZ, E.; LANDEROSFLORES, J.; OCHOA-FUENTES, Y.; GARCÍA-LÓPEZ, A.M.; GONZÁLEZ, R.E. Efecto de insecticidas sobre la mortalidad y depredación de Chrysoperla carnea (Neuroptera: Chrysopidae). Southwestern Entomologist, Washington, v.40, n.3, p.565-575, 2015.

ALROUECHDI, K. Les chrysopides (Neuroptera) récoltés dans une oliveraie du sud-est de la France. Paris, 1980.

ANDRÉS-CANTERO, F. Enfermedades y plagas plivo. Jaén: Riquelme y Vargas, 1997.

ARAMBOURG, Y. Traité d'entomologie oléicole. Madrid: Conseil Oléicole International, 1986.

ASPÖCK, H. The biology of Raphidioptera: a review of present knowledge. Acta Zoologica Academiae Scientiarum Hungaricae, Budapest, v.48, n.2, p.35-50, 2002.

BEEMAN, R.W.; MATSUMURA, F. Anorectic effect of chlordimeform in the American cockroach. Journal of Economic Entomology, Laham, v.71, n.6, p.859-861, 1978.

BEJARANO-ALCÁZAR, J.D.; RODRÍGUEZ-JURADO, J.M.; DURÁN-ÁLVARO, M.; RUIZ-TORRES, M.; HERRERA-MÁRMOL. Control de enfermedades $\mathbf{y}$ plagas en producción integrada del olivar. Producción Integrada de Olivar. Sevilla: Instituto de Investigación y Formación Agraria y Pesquera p.55-90, 2011. (Unidad didáctica 5)

BOLLERO, A.L.; MOYA, J.H.; MACÍAS, V.V.; MOHEDANO, D.P.; MOYA, J.C.H. Introducción al olivar ecológico en Andalucía. Sevilla: Instituto de Investigación y Formación Agraria y Pesquera, Junta de Andalucía, 2017.

BOZSIK,A. Pesticidetesting on adults of the Chrysoperla carnea-complex (Neuroptera: Chrysopidae) and the sibling species problem in the toxicology of common green lacewings. In: INTERNATIONAL SYMPOSIUM ON NEUROPTEROLOGY, 10., 2008. Piran. Proceedings [...]. Maribor: Faculty of Natural Sciences and Mathematics, 2010.
BOZSIK, A.; GONZÁLEZ-RUIZ, R.; LARA, B.H. Distribution of the Chysoperla carnea complex in southern Spain (Neuroptera: Chrysopidae). Analele Universității din Oradea, Fascicula: Protecția Mediului, Oradea, v.14, p.60-65, 2009.

BURRACK H.J.; FORNELL, A.M.; CONNELL, J.H.; O'CONNELL, N.V.; PHILLIPS, P.A.; VOSSEN, P.M.; ZALOM, F.G. Intraspecific larval competition in the olive fruit fly (Diptera: Tephritidae). Environmental Entomology, College Park, v.38, n.5, p.1400-1410, 2009.

CALABRESE, G.; TARTAGLINI, N.; LADISA, G. Study on biodiversity in century-old olive groves. Bari: CIHEAM-Mediterranean Agronomic Institute, 2012.

CAMPOS, M. Contribución al estudio de la entomocenosis de Prays oleae Bern.(Lep. Hyponomeutidae) en Granada (España). Acta Oecologia: Oecologia Applicata, Montreuil , v.2, n.1, p.27-35, 1981.

CAMPOS, M.; RAMOS, P. Some relationships between the number of Prays oleae eggs laid on olive fruits and their predation by Chrysoperla carnea. In: CEC/FAO/ IOBC INTERNATIONAL JOINT MEETING, 1984, Pisa. Proceedings [...]. Brussel: Commission of the European Communities, 1985 .

CANARD, M. Chrysopides (Neuroptera) récoltés dans les oliveraies en Grèce. Biologia Gallo-Hellenica, Toulouse, v.8, p.237-240, 1979.

CARRERO, J.M. Lucha integrada contra las plagas agrícolas y forestales. Madri: Mundi-Prensa, 1996.

CORREA, Y.D.C.G.; FARONI, L.R.; HADDI, K.; OLIVEIRA, E.E.; PEREIRA, E.J.G. Locomotory and physiological responses induced by clove and cinnamon essential oils in the maize weevil Sitophilus zeamais. Pesticide Biochemistry and Physiology, Amsterdam, v.125, p.31-37, 2015.

DE LIÑÁN, C. Entomología agroforestal. Insectos y ácaros que dañan montes, cultivos y jardines. Madrid: Editorial Tecnoagricola, 1998.

DEL PUERTO RODRÍGUEZ, A,M; SUÁREZTAMAYO, S.; PALACIO ESTRADA, D.E. Efectos de los plaguicidas sobre el ambiente y la salud. Revista Cubana de Higiene y Epidemiología, La Habana, v.52, n.3, p.372-387, 2014. 
DESNEUX, N.; DECOURTYE, A.; DELPUECH, J. The sublethal effects of pesticides on beneficial arthropods. Annual Review of Entomology, Palo Alto, v.52, p.81-106, 2007.

EHI-EROMOSELE, C.; NWINYI, O.C.; AJANI, O.O. Weed and pest control. Conventional and new challenges. London: IntechOpen Limited, 2013.

FRANÇA, S.M.D.; BREDA, M.O.; BARBOSA, D.R.; ARAUJO, A.M.; GUEDES, C.A. The sublethal effects of insecticides in insects. In: SHIELDS, V.D.C. (ed.). Biological control of pest and vector insects. London: IntechOpen Limited, 2017. p.23.

GEORGHIOU, G.P. The evolution of resistance to pesticides. Annual Review of Ecology and Systematics, Palo Alto, v.3, n.1, p.133-168, 1972.

GEROLD, J.; LAARMAN, J. Behavioural responses to contact with DDT in Anopheles atroparvus. Nature, London, v.215, n.5100, p.518-520, 1967.

GÓMEZ, J.A.; CAMPOS, M.; GUZMÁN, G.; CASTILLOLLANQUE, F.; VANWALLEGHEM, T.; LORA, Á.; GIRÁLDEZ, J.V. Soil erosion control, plant diversity, and arthropod communities under heterogeneous cover crops in an olive orchard. Environmental Science and Pollution Research, Landsberg, v.25, n.2, p.977-989, 2018.

GÓMEZ-GUZMÁN, J.A.; GARCÍA-MARÍN, F.J.; SÁINZ-PÉREZ, M.; GONZÁLEZ-RUIZ, R. Behavioural resistance in insects: its potential use as bio indicator of organic agriculture. In: IOP CONFERENCE SERIES: EARTH AND ENVIRONMENTAL SCIENCE, 2017, Shangai. Bristol: IOP Publishing, 2017.

GONZÁLEZ-RUIZ, R. Estudio bioecológico de Phloeotribus scarabaeoides Bernard (coleoptera, scolytidae) en la provincia de Granada. 1989. Tesis (Dcotor) - Universidad de Granada, Facultad de Ciencias, Granada, 1989.

GONZÁLEZ-RUIZ, R.; AL-ASAAD, S.; BOZSIK, A. Influencia de las masas forestales en la diversidad y abundancia de los crisópidos (Neur.:" Chrysopidae") del olivar. Cuadernos de la Sociedad Española de Ciencias Forestales, Pontevedra, n.26, p.33-38, 2008.
GONZÁLEZ-RUIZ, R.; GÓMEZ-GUZMÁN, J.A. Agricultural management greatly affects the beneficial entomofauna of the olive groves. American Journal of Biomedical Science \& Research, Orange, v.1, n.3, 2019.

GOULD, F. Role of behavior in the evolution of insect adaptation to insecticides and resistant host plants. Bulletin of the Entomological Society of America, Baltimore, v.30, n.4, p.34-41, 1984.

GUEDES, N.M.P.; GUEDES, R.N.C.; FERREIRA, G.H.; SILVA, L.B. Flight take-off and walking behavior of insecticide-susceptible and-resistant strains of Sitophilus zeamais exposed to deltamethrin. Bulletin of Entomological Research, Cambridge, v.99, n.4, p.393, 2009.

GUERRERO GARCÍA, A. Nueva olivicultura. Madrid: Ed.Mundi-Prensa, 2003.

HADDI, K.; OLIVEIRA, E.E.; FARONI, L.R.; GUEDES, D.C.; MIRANDA, N.N. Sublethal exposure to clove and cinnamon essential oils induces hormetic-like responses and disturbs behavioral and respiratory responses in Sitophilus zeamais (Coleoptera: Curculionidae). Journal of Economic Entomology, Laham, v.108, n.6, p.28152822, 2015.

HAYNES, K.; LI, W.; BAKER, T.Control of pink bollworm moth (Lepidoptera: Gelechiidae) with insecticides and pheromones (attracticide): lethal and sublethal effects. Journal of Economic Entomology, Laham, v.79, n.6, p.1466-1471, 1986.

HAYNES, K.F. Sublethal effects of neurotoxic insecticides on insect behavior. Annual Review of Entomology, Palo Alto, v.33, n.1, p.149-168, 1988.

HENRY, C.S.; BROOKS, S.J.; DUELLI, P.; JOHNSON, J.B. A lacewing with the wanderlust: the European song species 'Maltese', Chrysoperla agilis, sp.n., of the carnea group of Chrysoperla (Neuroptera: Chrysopidae). Systematic Entomology, Oxford, v.28, n.2, p.131-148, 2003.

HENRY, C.S.; BROOKS, S.J.; THIERRY, D.; DUELLI, P.; JOHNSON, J.B. The common green lacewing (Chrysoperla carnea s.lat.) and the sibling species problem. In: McEWEN, P.K.; NEW, T.R.; WHITTINGTON, A.E. Lacewings in the crop environment. Cambridge Cambridge University Press, 2001. p.29-41. 
HODKINSON, I.D.; M.K.HUGHES. La fitofagia en los insectos. Barcelona: Oikos-Tau, 1993.

HURLBERT, S.H. Pseudoreplication and the design of ecological field experiments. Ecological Monographs, Durhan, v.54, n.2, p.187-211, 1984.

KATSOYANNOS, P. Olive pests and their control in the Near East. Roma: FAO, 1992. (Plant Production and Protection Paper, 115)

KENNEDY, J. The excitant and repellent effects on mosquitos of sub-lethal contacts with DDT. Bulletin of Entomological Research, Cambridge, v.37, n.4, p.593607,1947

KEVAN, P.G. Pollinators as bioindicators of the state of the environment: species, activity and diversity. Agriculture, Ecosystems \& Environment, Amsterdam, v.74, n.1/3, p.373-393, 1999.

KHAN-PATHAN, A.; SAYYED, A.H.; ASLAM, M.; RAZAQ, M.; JILANI, G.; SALEEM, M.A. Evidence of field-evolved resistance to organophosphates and pyrethroids in Chrysoperla carnea (Neuroptera: Chrysopidae). Journal of Economic Entomology, Laham, v.101, n.5, p.1676-1684, 2008.

KONGMEE, M.; PRABARIPAI, A.; AKRATANAKUL, P.; BANGS, M.J.; CHAREONVIRIYAPHAP, T. Behavioral responses of Aedes aegypti (Diptera: Culicidae) exposed to deltamethrin and possible implications for disease control. Journal of Medical Entomology, Laham, v.41, n.6, p.1055-1063, 2004.

LEE, C. Sublethal effects of insecticides on longevity, fecundity and behaviour of insect pests: a review. Journal of Bioscience, Penang, v.11, n.1, p.107-112, 2000.

LEVINSON, H.Z. Possibilities of using insectistatics and pheromones in pest control. Die Naturwissenschaften, Berlin, v.62, n.6, p.272-282, 1975.

LOCKWOOD,J.A.; SPARKS, T.C.; STORY, R.N.Evolution of insect resistance to insecticides: a reevaluation of the roles of physiology and behavior. Bulletin of the Entomological Society of America, Baltimore, v.30, n.4, p.41-51, 1984 .

LUCKMANN, W.H.; METCALF, R.L. Introducción al manejo de plagas de insectos. México: Limusa, 1990.
LUND, A.E.; HOLLINGWORTH, R.M.; SHANKLAND, D.L. Chlordimeform: plant protection by a sublethal, noncholinergic action on the central nervous system. Pesticide Biochemistry and Physiology, Amsterdam, v.11, n.1-3, p.117-128, 1979.

MAZZI, D.; DORN, S.Movement of insect pests in agricultural landscapes. Annals of Applied Biology, Cambridge, v.160, n.2, p.97-113, 2012.

MOORE, R. Behavioral and biological effects of NRDC161 as factors in control of the boll weevil. Journal of Economic Entomology, Lahan, v.73, n.2, p.265-267, 1980 .

MORENO, M.J.; SORIANO, C.C. Control integrado de plagas en el olivar andaluz. Phytoma España: La revista profesional de sanidad vegetal, Valencia, n.219, p.56-63, 2010.

NAVE, A.; GONÇALVES, F.; NUNES, F.M.; CAMPOS, M.; TORRES, L. Evaluating potential sugar food sources from the olive grove agroecosystems for Prays oleae parasitoid Chelonus elaeaphilus. Biocontrol Science and Technology, Abingdon, v.27, n.5, p.686-695, 2017.

NIKOLOVA, I.; GEORGIEVA, N.; TAHSIN, N. Toxicity of neem and pyrethrum products applied alone and in combination with different organic products to some predators and their population density. Romanian Agricultural Research, Fundulea, v.32, n.32, p.291-301, 2015 .

PANTALEONI, R.A. Perspectivas del uso de Raphidioptera y Neuroptera Coniopterygidae como agentes de control biológico. In: BARREA, A. Teoría y Aplicación del Control Biológico. México: Sociedad Mexicana de Control Biológico, 2007. p.106-126.

PASCUAL, S.; COBOS, G.; SERIS, E.; SÁNCHEZRAMOS, I.; GONZÁLEZ-NÚÑEZ, M. Spinosad bait sprays against the olive fruit fly (Bactrocera oleae (Rossi)): effect on the canopy non-target arthropod fauna. International Journal of Pest Management, Abingdon, v.60, n.4, p.258-268, 2014.

PIKE, K.S.; MAYER, D.F.; GLAZER, M.; KIOUS, C. Effects of permethrin on mortality and foraging behavior of honey bees in sweet corn. Environmental Entomology, College Park, v.11, n.4, p.951-953, 1982. 
PLUTHERO, F.G.; SINGH, R.S. Insect behavioural responses to toxins: practical and evolutionary considerations. The Canadian Entomologist, Ottawa, v.116, n.1, p.57-68, 1984.

QUISENBERRY, S.S.; LOCKWOOD, J.A.; BYFORD, R.L.; WILSON, H.K.; SPARKS, T.C. Pyrethroid resistance in the horn fly, Haematobia irritans (L.) (Diptera: Muscidae). Journal of Economic Entomology, Lahan, v.77, n.5, p.1095-1098, 1984.

RAMOS, P.; RAMOS, J.M. Veinte años de observaciones sobre la depredación oófaga en Prays oleae Bern. Granada (España), 1970-1989. Boletín de Sanidad Vegetal Plagas, Madrid, v.16, p.119-127, 1990.

ROLFF, J.; REYNOLDS, S. Insect infection and immunity: evolution, ecology, and mechanisms. Oxford: University Press, 2009.

ROZAS, L.; GONZÁLEZ-RUIZ, R. Sobre los Raphidioptera (Insecta: Neuropteroidea) en olivares de Jaén y la influencia de las cubiertas vegetales. 2017.

SÁNCHEZ, M.; LÓPEZ-VILLALTA, M.C. Lucha integrada: Control integrado en el olivar español y su influencia en la calidad. Agricultura: Revista Agropecuaria Y Ganadera, n.735, p.854-858, 1993.

SINGH, J.P.; MARWAHA, K.K. Effect of sublethal concentrations of some insecticides on growth and development of maize stalk borer, Chilo partellus (Swinhoe) larvae. Shashpa, Delhi, v.7, n.2, p.181-186, 2000 .

STARK, J.D.; JEPSON, P.C.; MAYER, D.F.L imitations to use of topical toxicity data for predictions of pesticide side effects in the field. Journal of Economic Entomology, Laham, v.88, n.5, p.1081-1088, 1995.

THIERRY, D.; CLOUPEAU, R.; JARRY, M.; CANARD, M. Discrimination of the West-Palaearctic Chrysoperla Steinmann species of the carnea Stephens group by means of claw morphology (Neuroptera, Chrysopidae). Acta Zoologica Fennica, Helsingforsiae, v.209, p.255-262, 1998.
THOMPSON, H.M. Behavioural effects of pesticides in bees-their potential for use in risk assessment. Ecotoxicology, Berlin, v.12, n.1-4, p.317330, 2003.

TRDAN, S.; ANDJUS, L.; RASPUDIĆ, E.; KAČ, M. Distribution of Aeolothrips intermedius Bagnall (Thysanoptera: Aeolothripidae) and its potential prey Thysanoptera species on different cultivated host plants. Journal of Pest Science, Berlin, v.78, n.4, p.217-226, 2005.

VAN DAME, R.; MELED, M.; COLIN, M.E.; BELZUNCES, L.P. Alteration of the homing-flight in the honey bee Apis mellifera L.Exposed to sublethal dose of deltamethrin. Environmental Toxicology and Chemistry: An International Journal, Pensacola, v.14, n.5, p.855-860, 1995.

VARELA-MARTÍNEZ, J.L.; GONZÁLEZ-RUIZ, R. Bases metodológicas para la evaluación del impacto ocasionado por las aplicaciones insecticidas sobre los enemigos naturales de las plagas del olivo (II). Phytoma España: La revista profesional de sanidad vegetal, Valencia, n.112, p.32-42, 1999.

VÉLEZ, M.; BERNARDES, R.C.; BARBOSA, W.F.; SANTOS, J.C.; GUEDES, R.N.C. Walking activity and dispersal on deltamethrin-and spinosad-treated grains by the maize weevil Sitophilus zeamais. Crop Protection, Guildford, v.118, p.50-56, 2019.

VIVES DE QUADRAS, J.M. Control de plagas de insectos. Problemas y alternativas. Insecticidas biorracionales. Madrid: CSIC. Colección Nuevas Tendencias, 1988. p.3-13. 